\title{
Assessment of genetic diversity in Brazilian barley using SSR markers
}

\author{
Jéssica Rosset Ferreira ${ }^{1}$, Jorge Fernando Pereira ${ }^{2}$, Caroline Turchetto ${ }^{2}$, Euclydes Minella ${ }^{2}$, Luciano Consoli $^{2}$ \\ and Carla Andréa Delatorre ${ }^{1}$ \\ ${ }^{1}$ Departamento de Plantas de Lavoura, Faculdade de Agronomia, \\ Universidade Federal do Rio Grande do Sul, Porto Alegre, RS, Brazil. \\ ${ }^{2}$ Embrapa Trigo, Passo Fundo, RS, Brazil.
}

\begin{abstract}
Barley is a major cereal grown widely and used in several food products, beverage production and animal fodder. Genetic diversity is a key component in breeding programs. We have analyzed the genetic diversity of barley accessions using microsatellite markers. The accessions were composed of wild and domesticated barley representing genotypes from six countries and three breeding programs in Brazil. A total of 280 alleles were detected, 36 unique to Brazilian barley. The marker Bmag120 showed the greatest polymorphism information content (PIC), with the highest mean value found on chromosome three, and the lowest on chromosomes four and six. The wild accessions presented the highest diversity followed by the foreign genotypes. Genetic analysis was performed using Principal Coordinates Analysis, UPGMA clustering, and Bayesian clustering analysis implemented in Structure. All results obtained by the different methods were similar. Loss of genetic diversity has occurred in Brazilian genotypes. The number of alleles detected in genotypes released in 1980s was higher, whereas most of the cultivars released thereafter showed lower PIC and clustered in separate subgroups from the older cultivars. The use of a more diverse panel of genotypes should be considered in order to exploit novel alleles in Brazilian barley breeding programs.
\end{abstract}

Keywords: Domesticated barley, genetic diversity, Hordeum vulgare ssp. vulgare, Hordeum vulgare ssp. spontaneum, microsatellite markers.

Received: June 05, 2015; Accepted August 25, 2015.

\section{Introduction}

Barley (Hordeum vulgare) was one of the first cereal species domesticated by humans and, since then, it is cultivated in several environments (Ladizinsky 1998; Feuillet et al., 2007). It is considered one of the best adapted cereals due to its tolerance to salinity, low temperatures and lower water demand (Baik and Ullrich, 2008; Goyal and Ahmed, 2012), although it is highly sensitive to aluminum (Bian et al., 2013). A broad range of end use, such as human consumption, malt in brewing and distilling industry and animal feeding, makes barley one of the most important cereal crops in the world ranking as the fourth most produced cereal after wheat, maize, and rice.

Cultivated barley (Hordeum vulgare ssp. vulgare) and its wild progenitor (Hordeum vulgare ssp. spontaneum) belong to the barley primary gene pool (Minella, 2005). Greater allelic diversity has been detected in wild than in cultivated barley (Saghai Maroof et al., 1994; Ledovskoy et al., 2010; Nandha and Singh, 2014).

Send correspondence to Carla Andréa Delatorre. Department of Crop Science, Agronomy School, Federal University of Rio Grande do Sul, PO Box 15096, 91501-970, Porto Alegre, RS, Brazil E-mail: cadtorre@ufrgs.br
The wild progenitor is of great interest for crop breeding because it carries a rich source of genes, enabling the adaptation to different biotic and abiotic stresses (Nevo et al., 2012). Moreover, these species preserved their intercrossing ability. The genetic diversity found in cultivated barley varies among different studies, some of them reporting high genetic diversity (Baik and Ullrich, 2008; Yahiaoui et al., 2008; Khodayari et al., 2012). Previous studies also showed different levels of genetic diversity in accessions of different geographic origins. For instance, genotypes from Europe showed lower genetic diversity compared to those of other continents (Malysheva-Otto et al., 2006).

In the last years, Brazil imported around 350 thousand tons yearly to supply the domestic needs, and $75 \%$ of the barley has been destined to produce malt for beer brewing (de Mori and Minella, 2012). Area expansion, and consequently production increase, would require the development of cultivars adapted to the diverse Brazilian environments. Hence, knowledge about the allelic composition of materials may facilitate the parental selection for breeding to specific environments. However, up to now, few genetic variability studies have been conducted for Brazilian barley. SDS-PAGE analysis was employed to an- 
alyze the hordein polypeptide patterns, which revealed a surprisingly extensive intravarietal polymorphism for Brazilian barley varieties (Echart-Almeida and CavalliMolina, 2000). The intravarietal variability was also detected by RAPD and isoenzymes, although in lower frequency (Selbach and Cavalli-Molina, 2000; Maris AF, 1992, Bachelor's thesis, Universidade Federal do Rio Grande do Sul, Porto Alegre, RS). However, a great genetic similarity was found among cultivars (Echart-Almeida and Cavalli-Molina, 2000; Kroth et al., 2005; Maris AF, 1992, Bachelor's thesis, Universidade Federal do Rio Grande do Sul, Porto Alegre, RS). Another good option for cultivar characterization is the use of microsatellite markers (SSR) that possess high levels of polymorphism, are multiallelic and spread throughout the genome (Gupta et al., 1996; Oliveira et al., 2006). Although SSR markers have been used to characterize barley from different countries (Saghai Maroof et al., 1994; Karakousis et al., 2003; Baik and Ullrich, 2008; Yahiaoui et al., 2008; Ledovskoy et al., 2010; Khodayari et al., 2012; Nandha and Singh, 2014), no studies evaluating the molecular diversity of Brazilian barley using this kind of markers have been conducted.

The objectives of the present study were to describe the molecular diversity of Brazilian barley, as well as to compare that diversity with the one found for foreign and wild genotypes. The aim was to detect new genetic variability and thus to assist the breeding programs in the development of new cultivars.

\section{Material and Methods}

\section{Plant material and genomic DNA isolation}

Seeds of 64 barley accessions, provided by the Active Germplasm Bank of CNPT-Embrapa, Brazil, were cultivated under controlled conditions. These accessions represent two- and six-row materials including six wild (Hordeum vulgare ssp. spontaneum) genotypes, 35 cultivars and 16 breeding lines developed by different breeding programs in Brazil, and seven cultivars from other countries (Table 1). The Brazilian accessions used here have spring growth habit and are representative of the germplasm cultivated in Brazil in the last four decades. Because we were interested in evaluating the genetic variability among the different Brazilian breeding programs (development institution), the wild and domesticated accessions, the breeding lines and cultivars, and among the Brazilian and foreign genotypes, we grouped the 64 barley accessions in seven sets according to development institution, country, and type as detailed in Table 2.

Young leaves of the seedlings were collected, transferred to $2 \mathrm{~mL}$ Eppendorf tubes containing three stainless steel beads ( $2.3 \mathrm{~mm}$ diameter) and immediately frozen in liquid nitrogen. Tissue was powdered using a Mini-Beadbeater ${ }^{\mathrm{TM}}$ (Biospec Products) platform and total genomic DNA was extracted using a CTAB protocol (Doyle and Doyle, 1987). The DNA quality and quantity

Table 1 - Barley genotypes used in this study.

\begin{tabular}{|c|c|c|c|c|c|}
\hline Genotype & Row & Institution & Country & Year & Pedigree \\
\hline Alpha & 2 & Foreign & USA & - & 'Manchuria'/'Champion of Vermont' \\
\hline Antarctica 01 & 2 & Cervejaria Antarctica Paulista & Brazil & 1960’s & Selection of Breun Volla \\
\hline Antarctica 04 & 2 & Cervejaria Antarctica Paulista & Brazil & 1999 & Alpha1959/Union \\
\hline Antarctica 05 & 2 & Cervejaria Antarctica Paulista & Brazil & 1999 & Unkown \\
\hline BRS 180 & 6 & CNPT/Embrapa & Brazil & 1999 & 73Ab2199/Karla \\
\hline BRS 195 & 2 & CNPT/Embrapa & Brazil & 2001 & Defra/BR 2 \\
\hline BRS 224 & 2 & CNPT/Embrapa & Brazil & 2002 & Embrapa 43/PFC 9114 \\
\hline BRS 225 & 2 & CNPT/Embrapa & Brazil & 2002 & PFC 9103/Defra \\
\hline BRS Brau & 2 & CNPT/Embrapa & Brazil & 2009 & MN 698/3/BRS 195//Schooner/Embrapa 129 \\
\hline BRS Cauê & 2 & CNPT/Embrapa & Brazil & 2008 & BRS Borema/BRS 195 \\
\hline BRS Elis & 2 & CNPT/Embrapa & Brazil & 2008 & BRS 195/Scarlett \\
\hline BRS Greta & 2 & CNPT/Embrapa & Brazil & 2006 & Krona/PFC 9219//PFC 9204 \\
\hline BRS Itanema & 2 & CNPT/Embrapa & Brazil & 2013 & BRS 195//PFC8590/PFC9205 \\
\hline BRS Lagoa & 2 & CNPT/Embrapa & Brazil & 2005 & PFC 9215/PFC 9288 \\
\hline BRS Marciana & 2 & CNPT/Embrapa & Brazil & 2005 & PFC 9240/PFC 9211 \\
\hline BRS Mariana & 2 & CNPT/Embrapa & Brazil & 2005 & PFC 88137/PFC 8905//PFC 9205 \\
\hline BRS Sampa & 2 & CNPT/Embrapa & Brazil & 2008 & BRS 195//PFC 8590/PFC 9205 \\
\hline BRS Suábia & 2 & CNPT/Embrapa & Brazil & 2006 & BRS 195/MN 698 \\
\hline Cevada BR1 & 2 & CNPT/Embrapa & Brazil & 1987 & $\begin{array}{l}\text { Selection of W } 5586 \\
=\text { Binder/Opal//Balder/kenia/3/Alpha }\end{array}$ \\
\hline
\end{tabular}


Table 1 (cont.)

\begin{tabular}{|c|c|c|c|c|c|}
\hline Genotype & Row & Institution & Country & Year & Pedigree \\
\hline Cevada BR2 & 2 & CNPT/Embrapa & Brazil & 1989 & FM 424/TR 206 \\
\hline Dayton & 6 & Foreign & USA & 1955 & Composite cross X (CI 6625) selection \\
\hline Embrapa 127 & 2 & CNPT/Embrapa & Brazil & 2000 & BR2/Alexis \\
\hline Embrapa 128 & 2 & CNPT/Embrapa & Brazil & 1999 & LM 844/PFC 84148//BR2 \\
\hline Embrapa 129 & 2 & CNPT/Embrapa & Brazil & 1999 & LM 844/MN610//Cevada BR 2 \\
\hline Embrapa 43 & 2 & CNPT/Embrapa & Brazil & 1999 & IPB 194//C 2146/TR 208 \\
\hline FM 404 & 2 & Maltaria Navegantes (Filial Maltaria) & Brazil & 1970’s & Selection from a cross probably involving Alpha \\
\hline FM 424 & 2 & Maltaria Navegantes (Filial Maltaria) & Brazil & 1970's & Quinn/Malteria Heda//W 5746 \\
\hline FM 434 & 2 & Maltaria Navegantes (Filial Maltaria) & Brazil & 1970 ’s & Quinn/Malteria Heda//FM 424 \\
\hline FM 437 & 2 & Maltaria Navegantes (Filial Maltaria) & Brazil & 1985 & Alpha 1959/2*Mansholt Twerijge Zomergerst \\
\hline FM 519 & 2 & Maltaria Navegantes (Filial Maltaria) & Brazil & 1985 & Kr 1/Union//Volla/3/Kr 2/Volla//Wisa/4/Alpha \\
\hline Golden Promise & 2 & Foreign & England & 1966 & Maythorpe Gamma-Ray Mutant \\
\hline Hspo 584 & 2 & - & - & - & - \\
\hline Hspo PI 282590 & 2 & - & Israel & - & - \\
\hline Hspo PI 466338 & 2 & - & Israel & - & - \\
\hline Hspo PI 466394 & 2 & - & Israel & - & - \\
\hline Hspo PI 466396 & 2 & - & - & - & - \\
\hline Hspo PI 466381 & 2 & - & Israel & - & - \\
\hline IAC 74310 & 2 & Instituto Agronômico de Campinas & Brazil & 1974 & Unkown \\
\hline IPB 1219 & 2 & International Plant Breeders & Brazil & 1980 & Vada/Zephyr \\
\hline IPB 194 & 2 & International Plant Breeders & Brazil & 1980 & Mazurka/Nackta \\
\hline MN 599 & 2 & Maltaria Navegantes & Brazil & 1990 & Ariana/Volla//FM 462 \\
\hline MN 6021 & 2 & Maltaria Navegantes & Argentina & 2012 & Dominique/Quilmes Ayelen \\
\hline MN 656 & 2 & Maltaria Navegantes & Brazil & 1993 & SG 4279/FM 404//Bacco/Union/3/ FM 434 \\
\hline MN 684 & 2 & Maltaria Navegantes & Brazil & 2001 & Antarctica 05/MN 577 \\
\hline MN 698 & 2 & Maltaria Navegantes & Brazil & 2001 & MN 599/MN 635 \\
\hline MN 743 & 2 & Maltaria Navegantes & Brazil & 2004 & MN 681/Gimpel \\
\hline Murasakimochi & 6 & Foreign & Japan & - & - \\
\hline Paraí-I & 6 & CNPT/Embrapa & Brazil & - & Unkown \\
\hline PFC 7802 & 2 & CNPT/Embrapa & Brazil & 7802 & Binder/Opal//Balder/Kenya \\
\hline PFC 8115 & 2 & CNPT/Embrapa & Brazil & 1981 & Volla*3/Wpgm 626-46-25 \\
\hline PFC 8153 & 2 & CNPT/Embrapa & Brazil & 1981 & FM 424*2//Volla/Wpgm 626-46-25 \\
\hline PFC 8280 & 2 & CNPT/Embrapa & Brazil & 1982 & Volla/C 2146 \\
\hline PFC 84148 & 2 & CNPT/Embrapa & Brazil & 1984 & Volla*3/Wpgm 626-46-25//MAGNIF 131 \\
\hline PFC 8601 & 2 & CNPT/Embrapa & Brazil & 1986 & Seleção em TR 207 em solo corrigido (1/8 SMP) \\
\hline PFC 8610 & 2 & CNPT/Embrapa & Brazil & 1986 & PFC 8144/Park \\
\hline PFC 86125 & 2 & CNPT/Embrapa & Brazil & 1986 & PFC 8153/IPB 194 \\
\hline PFC 8644 & 2 & CNPT/Embrapa & Brazil & 1986 & Antarctica $05 * 3 /$ Park \\
\hline PFC 88209 & 6 & CNPT/Embrapa & Brazil & 1988 & Selection of FM 70 \\
\hline PFC 88210 & 6 & CNPT/Embrapa & Brazil & 1988 & Selection of FM 71 \\
\hline PFC 88211 & 6 & CNPT/Embrapa & Brazil & 1988 & Selection of FM 80 \\
\hline PFC 88212 & 6 & CNPT/Embrapa & Brazil & 1988 & Selection of FM 80 \\
\hline Quench & 2 & Foreign & England & - & Sebastian/Drum \\
\hline Quest & 6 & Foreign & USA & - & MN Brite/Zhedar 1 \\
\hline Vacaria & 6 & CNPT/Embrapa & Brazil & - & Unkown \\
\hline
\end{tabular}


Table 2 - Groups of genotypes separated according to institution, country and barley type.

\begin{tabular}{lccccccc}
\hline & $\begin{array}{c}\text { CNPT/Embrapa } \\
\text { cultivars }\end{array}$ & $\begin{array}{c}\text { Companhia } \\
\text { Antarctica } \\
\text { Paulista }\end{array}$ & $\begin{array}{c}\text { Maltaria } \\
\text { Navegantes }\end{array}$ & $\begin{array}{c}\text { Breeding lines } \\
\text { from other } \\
\text { institutions }\end{array}$ & $\begin{array}{c}\text { Breeding lines } \\
\text { from } \\
\text { CNPT/Embrapa }\end{array}$ & $\begin{array}{c}\text { Foreign } \\
\text { genotypes }\end{array}$ & Wild barley \\
\hline Number of genotypes & 22 & 3 & 10 & 3 & 13 & 7 & 6 \\
Total of alleles & 146 & 61 & 105 & 63 & 130 & 123 & 145 \\
Alleles per locus & 4.29 & 1.79 & 3.09 & 1.85 & 3.82 & 3.62 & 4.26 \\
PIC & 0.46 & 0.27 & 0.43 & 0.32 & 0.52 & 0.57 & 0.63 \\
\hline
\end{tabular}

${ }^{1}$ Lines from Instituto Agronômico de Campinas and International Plant Breeders.

${ }^{2}$ Genotypes identified in Table 1 as "PFC".

was estimated on $0.8 \%$ agarose gels. DNA was stored at -20 ${ }^{\circ} \mathrm{C}$ for further analyses.

\section{Microsatellite (SSR) amplification}

Genomic DNA was amplified using 34 previously described SSR markers (Liu et al., 1996; Röder et al., 1998; Ramsay et al., 2000; Varshney et al., 2007; Soto-Cerda et al., 2013) that are scattered throughout the barley genome. The details of the 34 SSR primers are available in Table S1.

PCR was conducted based on a three primer system, as described by Schuelke (2000), where one of the locus-specific primers (forward or reverse) was extended with a non-labeled M13-tail (TGTAAAACGAC GGCCAGT), and a M13 primer labeled with a fluorescent dye (FAM, NED, PET or VIC). The reaction mixture was prepared in a final volume of $10 \mu \mathrm{L}$ containing $1 \mathrm{x}$ buffer (RBC Bioscience), $0.2 \mu \mathrm{M}$ primer, $0.02 \mu \mathrm{M}$ M13 tailed primer and $0.2 \mu \mathrm{M}$ fluorescence-labeled M13 primer. Other reagents were optimized for each primer and added as mixA $\left[1.5 \mathrm{mM} \mathrm{MgCl}_{2}\right.$ (RBC Bioscience), $0.2 \mathrm{mM}$ of each dNTP (Thermo Scientific), 0.5 U of Taq polymerase (RBC Bioscience)], mix C [2.5 $\mathrm{mM} \mathrm{MgCl}_{2}, 0.2 \mathrm{mM}$ of each dNTP, $0.75 \mathrm{U}$ of Taq polymerase], or mixD [2.5 mM $\mathrm{MgCl}_{2}, 0.35 \mathrm{mM}$ of each dNTP, $0.75 \mathrm{U}$ of Taq polymerase]. Amplification was performed in a GenAmp ${ }^{\circledR}$ PCR System 9700 (Applied Biosystems) with two programs set according to the melting temperatures of the primers (Table $\mathrm{S} 1)$ : TD60-50 $\left(94^{\circ} \mathrm{C}\right.$ for $30 \mathrm{~s}, 60^{\circ} \mathrm{C}$ for $30 \mathrm{~s}$, and $72^{\circ} \mathrm{C}$ for $30 \mathrm{~s}$, followed by 10 cycles at decreasing annealing temperatures of $1{ }^{\circ} \mathrm{C}$ per cycle and then 30 cycles at $94{ }^{\circ} \mathrm{C}$ for $30 \mathrm{~s}$, $50{ }^{\circ} \mathrm{C}$ for $30 \mathrm{~s}, 72^{\circ} \mathrm{C}$ for $30 \mathrm{~s}$ ), or TD60-55 (94 ${ }^{\circ} \mathrm{C}$ for $30 \mathrm{~s}$, $60{ }^{\circ} \mathrm{C}$ for $30 \mathrm{~s}$, and $72^{\circ} \mathrm{C}$ for $30 \mathrm{~s}$, followed by five cycles at decreasing annealing temperatures of $1^{\circ} \mathrm{C}$ per cycle and then 35 cycles at $94^{\circ} \mathrm{C}$ for $30 \mathrm{~s}, 55^{\circ} \mathrm{C}$ for $30 \mathrm{~s}, 72^{\circ} \mathrm{C}$ for 30 $\mathrm{s})$. After amplification, the reactions from up to four primer combinations containing different fluorescent dyes were multiplexed, diluted, mixed with Hi-Di formamide and GeneScan 500 LIZ size standard (Applied Biosystems), denatured and run on an ABI 3130xL Genetic Analyzer containing a $36 \mathrm{~cm}$ capillary array with POP7 polymer. The program GeneMapper v3.5 was used to determine allele sizes.

\section{Data analysis}

FSTAT 2.9.3.2 software (Goudet, 2002) was used to evaluate summary statistics, such as the number of alleles per locus $(A)$ and number of private alleles $(E)$ for each locus and groups of accessions. Polymorphism information content (PIC) was estimated using the PowerMarker software (Liu and Muse, 2005) according to Anderson et al. (1993): $\mathrm{PIC}=1-\Sigma \mathbf{P}_{i j}{ }^{2}$, where $\mathrm{P}_{i j}$ is the frequency of the $i$ th allele at the $j$ th marker, to evaluate the diversity level of each SSR marker. In addition, we implemented analyses of molecular variance (AMOVA; Excoffier et al., 1992) using ARLEQUIN 3.5.1.2 software (Excoffier and Lischer, 2010) among seven groups of accessions. Grouping of the accessions was established according to the institution that developed the cultivars or breeding lines (Table 1). The genetic diversity among Brazilian genotypes developed in different decades was estimated based on the number of alleles, frequency of alleles and PIC values.

To investigate the genetic similarity between accessions, we carried out a Principal Coordinates Analysis in GENALEX 6.4 software (Peakall and Smouse, 2006, 2012). A matrix of distance based on shared alleles among accessions was used to depict relationships among all accessions; the original data were bootstrapped 10,000 times using PowerMarker software (Liu and Muse, 2005). In addition, an Unweighted Pair Group Method with Arithmetic Mean (UPGMA) tree was constructed based on the matrix of shared microsatellite alleles among the 64 accessions calculated from 34 SSRs using the PowerMarker software (Liu and Muse, 2005). A Bayesian clustering analysis as implemented in STRUCTURE 2.3 software (Pritchard et al., 2000) was performed to compare to UPGMA and PCoA results. This approach uses a Bayesian clustering analysis to assign individuals to clusters $(\mathrm{K})$ without prior knowledge of their population affinities. The parameters were correlated to allele frequencies (Falush et al., 2003) and no prior accession information was used. The number of groups (K) was evaluated from one to 20, with 10 independent runs per $\mathrm{K}$ value, to determine the maximum value of the posterior likelihood $[\ln P(D)]$ and the best value of $\mathrm{K}$. Each run was performed using $2.510^{5}$ burn-in periods and $10^{6}$ Markov chain Monte Carlo (MCMC) repetitions after 
burn-in, and the convergence was checked. The optimal value of $\mathrm{K}$ was calculated using the maximum value of $\Delta \mathrm{K}$ (Evanno et al., 2005) implemented in STRUCTURE HARVESTER 0.6.93 (Earl and von Holdt, 2012). CLUMPP 1.1.2 software was used to summarize the results of the optimal $\mathrm{K}$ value on the basis of the average pairwise similarity of individual assignments across runs using Greedy's method and the G' statistic (Jakobsson and Rosenberg, 2007). DISTRUCT 1.1 software (Rosenberg, 2004) was used to visualize the STRUCTURE results after processing with the CLUMPP software.

\section{Results}

\section{Genetic variation}

We have evaluated 34 SSR loci in 64 barley accessions including two- and six-row genotypes as well as wild and domesticated barley. Although 11 genotypes from six countries are among the ones studied here, the majority of accessions represent genotypes developed in Brazil. The 34 markers were spread through the barley genome with at least four markers on each chromosome. We detected 280 alleles with an average of eight alleles per locus. The number of alleles per locus varied from one for markers XGWM6, HvLOX and Bmac0251 (monomorphic loci) to 18 for the marker Bmag0032 (Table 3). Sixteen markers detected at least 10 alleles and only eight amplified less than five alleles. For only one marker (Bmac0167), a null allele was observed. An association between the number of motif repeats and the number of alleles could be established. On average, loci containing 15 or more motif repeats generated 10 alleles per marker while the ones with less than 15 motif repeats showed five alleles per marker. Among the monomorphic loci, two contained less than 15 motif repeats while one (XGWM6) possessed the highest number (40 repeats) among the evaluated markers. The highest number of alleles was found in the 22 cultivars developed by CNPTEmbrapa (146 alleles averaging four alleles per locus) and in the six wild accessions (145 alleles averaging four alleles per locus). However, considering the number of accessions within each set, the foreign genotypes also generated a high number of alleles (Table 2).

Private alleles were detected in all sets except from Companhia Antarctica Paulista (Table S2). In the wild accessions, 69 private alleles were detected in 28 different loci (Table S2). Among the foreign genotypes and the cultivars developed by CNPT-Embrapa we found 23 and 21 private alleles, respectively. Only one private allele was visualized in the breeding lines developed by other institutions. The Bmag0032 marker was the locus with the highest number of alleles and presented the highest number of private alleles (Table S2).

Furthermore, indicators of locus diversity (polymorphism information content - PIC) were calculated (Table 3). Large variation was observed among the polymorphic
Table 3 - Repeat motif, number of alleles, allele size range, and polymorphism information content (PIC) of the 34 SSR markers used.

\begin{tabular}{|c|c|c|c|c|}
\hline Marker & Repeat motif & $\begin{array}{l}\text { Number } \\
\text { of alleles }\end{array}$ & $\begin{array}{l}\text { Allele size } \\
\text { range }\end{array}$ & PIC \\
\hline Bmac0090 & (AC)20 & 10 & $207-247$ & 0.75 \\
\hline Bmag0032 & $(\mathrm{AC}) 7 \mathrm{~T}(\mathrm{CA}) 15(\mathrm{AT}) 9$ & 18 & 211-319 & 0.78 \\
\hline Bmag211 & (CT) 16 & 6 & $193-207$ & 0.54 \\
\hline HVM20 & $(\mathrm{GA}) 19$ & 6 & $150-172$ & 0.66 \\
\hline Bmag0125 & (AG)19 & 10 & $136-162$ & 0.77 \\
\hline Bmag0378 & (AG)14 & 8 & $150-170$ & 0.26 \\
\hline Bmag0749 & (AG)11 & 4 & $180-186$ & 0.62 \\
\hline HVM36 & $(\mathrm{GA}) 13$ & 6 & $124-166$ & 0.65 \\
\hline HVM54 & (GA)14 & 7 & $166-182$ & 0.58 \\
\hline Bmac0067 & (AC) 18 & 9 & $180-250$ & 0.72 \\
\hline Bmag0013 & (CT) 21 & 12 & $147-183$ & 0.81 \\
\hline Bmag225 & (AG)26 & 10 & $155-185$ & 0.81 \\
\hline HVM60 & $(\mathrm{AG}) 11(\mathrm{GA}) 14$ & 10 & $101-133$ & 0.77 \\
\hline Bmac0030 & (AC)22 & 11 & $150-180$ & 0.83 \\
\hline Bmac0310 & (CT)11(AC)20 & 11 & $159-199$ & 0.76 \\
\hline Bmag0353 & $(\mathrm{AG}) 21$ & 11 & $105-145$ & 0.69 \\
\hline EBmac0669 & $(\mathrm{AC}) 8$ & 2 & $236-238$ & 0.07 \\
\hline EBmag0781 & (CT) 21 & 4 & $162-182$ & 0.26 \\
\hline HVM68 & (GA)22 & 12 & $196-240$ & 0.77 \\
\hline HvML03 & (CTT)6 & 3 & $251-266$ & 0.33 \\
\hline wms 165 & (GA)20 & 8 & $215-263$ & 0.23 \\
\hline XGWM6 & (GA)40 & 1 & 196 & 0.00 \\
\hline Bmac0113 & $(\mathrm{AT}) 7(\mathrm{AC}) 18$ & 10 & $208-236$ & 0.81 \\
\hline Bmac096 & (AT)6(AC)16 & 11 & $180-212$ & 0.77 \\
\hline Bmag0387 & (AG)16 & 8 & $119-161$ & 0.53 \\
\hline HvLOX & $(\mathrm{AG}) 9$ & 1 & 170 & 0.00 \\
\hline Bmac0316 & (AC)19 & 14 & $142-200$ & 0.66 \\
\hline Bmac251 & $(\mathrm{AC}) 12 \mathrm{~A}(\mathrm{AC}) 13$ & 1 & 161 & 0.00 \\
\hline Bmag0173 & (CT) 29 & 8 & $156-180$ & 0.79 \\
\hline HVM65 & $(\mathrm{GA}) 10$ & 3 & $139-143$ & 0.30 \\
\hline Bmac0031 & $\mathrm{AC}(28)$ & 10 & $172-211$ & 0.53 \\
\hline Bmac0167 & $\mathrm{AC}(20)$ & $10^{1}$ & $180-212$ & 0.76 \\
\hline Bmag0120 & (AG)15 & 17 & $230-290$ & 0.86 \\
\hline Bmag0135 & (AG)10GG(AG)12 & 8 & $133-179$ & 0.79 \\
\hline
\end{tabular}

${ }^{1}$ Null allele was observed.

loci; PIC values ranged from 0.07 (EBmac0669) to 0.86 (Bmag120) with an average of 0.57 . Not considering the monomorphic loci, only five markers originated PIC values below 0.50 , therefore the majority of the markers were moderately to highly informative, according to the criteria proposed by Botstein et al. (1980). Among the five loci with PIC $<0.50$, three were located on chromosome four. Chromosomes four and six showed the lowest mean PIC value (0.43) among all chromosomes. Among the different sets, the highest PIC value was observed for wild barley 
(0.63) evidencing higher genetic diversity in these accessions. The second highest PIC value was found in the foreign genotypes (0.57), while PIC values varied from 0.27 (Companhia Antarctica Paulista) to 0.46 (CNPT-Embrapa) among the cultivars developed by the different breeding programs in Brazil. The PIC value considering all Brazilian genotypes (cultivars and breeding lines) was 0.51 . It indicates a lower genetic diversity compared with foreign (0.57) and wild (0.63) accessions. Furthermore, the PIC value was lower among Brazilian genotypes developed in the last two decades in comparison to materials released in the 1980s (Figure 1A) suggesting a trend toward decreased diversity. The loss of genetic diversity is also supported by the statistically superior number of alleles detected in the genotypes developed in the 1980s (Figure 1B). Moreover, a change in the frequency of alleles was clearly observed between genotypes developed in the 1980s and 2000s where a reduced number of alleles per marker was observed in the genotypes developed in the 2000s (Figures 1C,D). The frequency of alleles per marker between genotypes from these two decades can be compared since a similar number of accessions developed in the 1980s and 2000s were analyzed (18 and 16, respectively).

\section{Genetic similarity}

In order to assess the clustering of barley accessions based on SSR polymorphism, we conducted a Principal Coordinates Analysis (PCoA). The scatter plots for the two first axes showed that accessions formed two principal groups (Figure 2A). The first group (small circle on the right-hand side of the PCA plot) was further subdivided into two. One subgroup (larger dotted circle in Figure 2A) contained all wild accessions, two CNPT-Embrapa culti-
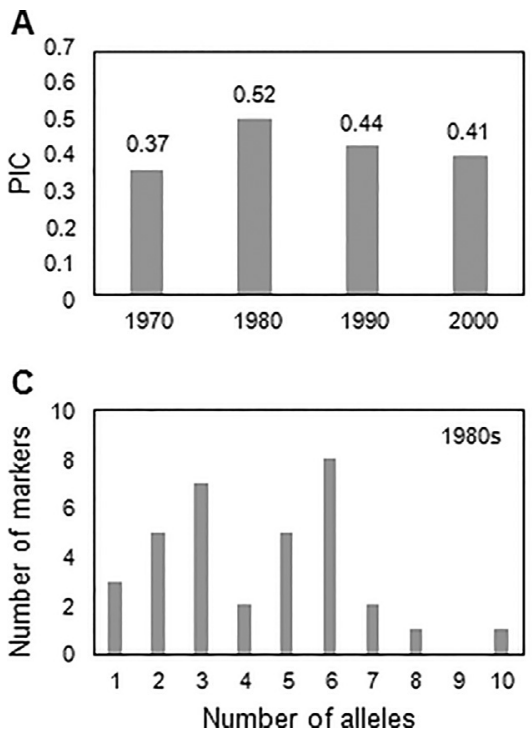

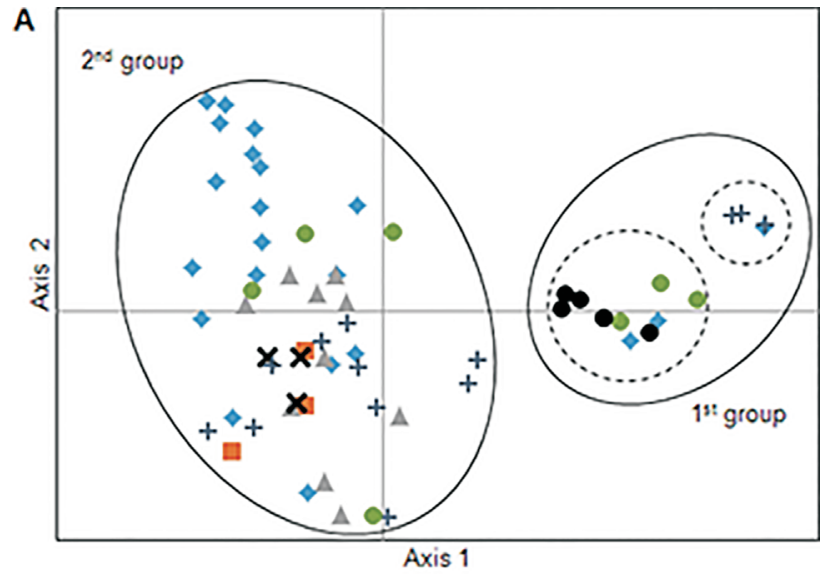

B

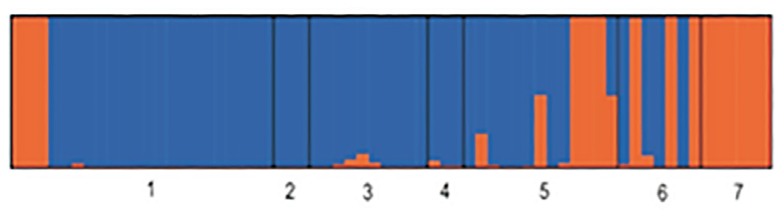

$\checkmark, 1$ CNPT-Embrapa cultivars; $\square, 2$ Companhia Antarctica Paulista cultivars; $A, 3$ Maltaria Navegantes cultivars; $\times$, 4 Breeding lines of other institutions; +,5 CNPT-Embrapa breeding lines; $\bullet, 6$ Foreign cultivars; and $\bullet, 7$ Wild accessions.

Figure 2 - Analysis plots of the barley accessions based on the polymorphism of 34 microsatellite markers. (A) By Principal Coordinate Analysis ( $\mathrm{PCoA})$ two groups were identified, with the first one separated into two subgroups. Two symbols, in the first group, indicating wild genotypes (Hspo PI 466394 and Hspo PI 466396), and another two in the second group, indicating CNPT-Embrapa cultivars (Cevada BR2 and Embrapa 127), overlapped. (B) Estimated proportion of membership in the corresponding clusters $(K=2)$ as calculated using STRUCTURE software.

vars (Paraí and BRS 180), and three foreign cultivars (Dayton, Quest and Murasakimochi), while the other subgroup (smaller dotted circle in Figure 2A) included three

B

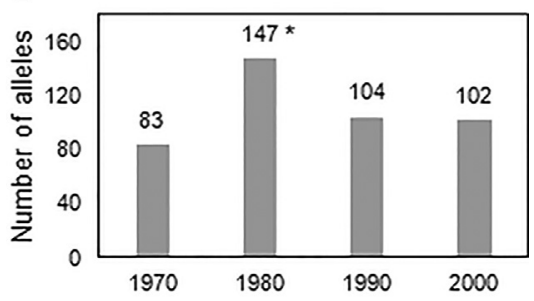

D

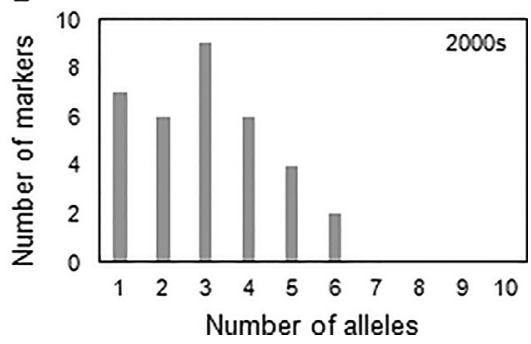

Figure 1 - PIC values (A) and total number of alleles (B) of the genotypes developed in Brazil in the last four decades. Frequency of alleles per marker is shown for genotypes developed in the 1980s (C) and after 2000 (D). Number of genotypes per decade are: 5 (1970); 18 (1980); 8 (1990) and 16 (2000). An asterisk indicates statistical difference by t-test $(\mathrm{p} \leq 0.05)$. 
CNPT-Embrapa breeding lines (PFC 88209, PFC 88210, and PFC 88211), and one CNPT-Embrapa cultivar (Vacaria). The second group (large circle on the left-hand side of the PCA plot) was composed of all other accessions and showed higher variation. Within this second group, the CNPT-Embrapa cultivars were scattered over a large area, with most of them being located in a separate region.

The AMOVA analysis revealed that $15 \%$ of the genetic variation $(\mathrm{P}<0.001)$ was distributed among the seven sets, representing the different breeding programs, countries and type of accession (wild/domesticated and breeding lines/cultivars), whereas $85 \%(\mathrm{P}<0.001)$ was within the sets. When we consider only accessions developed in Brazil, the AMOVA showed $12 \%$ of the genetic variation among sets, and $88 \%(\mathrm{P}<0.001)$ within sets $(\mathrm{P}<0.001)$. These results indicated that the genetic variation within the sets contributed to most of the genetic diversity detected.

The UPGMA cluster analysis produced three main groups (named as Groups A, B and C) (Figure 3). Group A consisted of all wild accessions except Hspo 584, which was clustered in the Group C. Besides Hspo 584, Group C also contained 10 other accessions represented by breeding lines and cultivars developed by CNPT-Embrapa and foreign genotypes. When comparing the accessions present in Groups $\mathrm{A}$ and $\mathrm{C}$ with the ones belonging to the first group detected by the PCoA analysis, only the line PFC 88212 was different between them revealing agreement patterns across analyses.

Group B in the dendrogram was the largest, consisting of 48 accessions representing four foreign materials and 44 Brazilian genotypes. This means that $86 \%$ of the Brazilian genotypes were clustered inside the same group. Group B was further substructured into five subgroups. Subgroup one consisted of three CNPT-Embrapa breeding lines and one cultivar developed by Maltaria Navegantes. Subgroup two contained breeding lines developed by CNPTEmbrapa and Instituto Agronômico de Campinas (IAC), cultivars released by CNPT-Embrapa, Companhia Antarctica Paulista and Maltaria Navegantes, and one foreign genotype (Alpha). Subgroup three consisted of cultivars developed by the three breeding programs in Brazil, while subgroup four was represented by cultivars and breeding lines developed by CNPT-Embrapa and by other institution. Finally, subgroup five included twelve CNPT-Embrapa cultivars, one cultivar developed by Maltaria Navegantes and two foreign genotypes (MN 6021 and Quench). Interestingly, Golden Promise appeared separated within this Group B. When considering the different breeding programs in Brazil, the genotypes developed by CNPT-Embrapa were the only ones distributed across more than one group and across all the subgroups within Group B.

The Bayesian clustering results, implemented in STRUCTURE software, were in agreement with the results of the PCoA and UPGMA analyses. In this analysis we observed that the best inferred number of clusters was $K=2$, obtained by the Evanno's method (Figure 2B). The major- ity of accessions of each group were grouped preferentially in one or the other cluster. Remarkably, the great majority of genotypes clustered in Group B by UPGMA analysis were assembled to the same group by Bayesian clustering. In addition, those clustering in Groups $\mathrm{A}$ and $\mathrm{C}$ were assigned to the other group. Exceptions were PFC 88212 and PFC 8610 that presented dual ancestry.

\section{Discussion}

Brazil ranks third among the countries with the largest beer production in the world. However, it produces only around 300 thousand tons of barley per year, which results in one of the largest barley import needs (de Mori and Minella, 2012). Therefore, increments in barley production are essential. The demand for higher yielding and betteradapted crop varieties has increased the necessity to exploit the genetic variation of genebank collections (Keilwagen et al., 2014). Evaluation of the genetic diversity of barley accessions can be an important source of information in order to discover and exploit novel alleles to be used in breeding programs. Here, for the first time, the SSR variability of Brazilian barley genotypes is reported. Although other groups have previously published molecular analyses of Brazilian barley accessions (Echart-Almeida and CavalliMolina, 2000; Kroth et al., 2005; Maris AF, 1992, Bachelor's thesis, Universidade Federal do Rio Grande do Sul, Porto Alegre, RS), the number of genotypes evaluated in this report is higher and also the use of SSR markers is advantageous when compared to RAPD or isoenzymes used previously. SSR marker analysis have proven to be a method of choice for marker-assisted selection in breeding and genetic diversity studies (Varshney et al., 2007), largely because they are highly informative and abundant in genomes, codominantly inherited and multiallelic (Gupta et al., 1996; Oliveira et al., 2006).

We successfully amplified 34 barley SSR barley loci obtaining an average of eight alleles for each locus. This is similar to the results reported for Iranian barley landraces (Khodayari et al., 2012), higher than the one reported for Indian barley (Jaiswal et al., 2010) and lower than the ones published by others (Saghai Maroof et al., 1994; Malysheva-Otto et al., 2006; Yahiaoui et al., 2008; Nandha and Singh, 2014). Here we obtained a mean PIC value of 0.57 , however, when considering just the Brazilian genotypes the diversity index was lower than that of foreign and wild accessions (Table 2), illustrating the low diversity in the Brazilian accessions. One interesting aspect is that in the UPGMA results (Figure 3) clusters seen inside Group B correlate with cultivar release date. Most of the accessions (77\%) in subgroups one and two are older genotypes developed between 1970 and 1988, while $79 \%$ of the genotypes in the other subgroups were developed between 1989 and 2013. Only one genotype developed after the year 2000 (MN 684) was clustered outside of subgroups three, four and five and, among the 13 Brazilian genotypes in sub- 


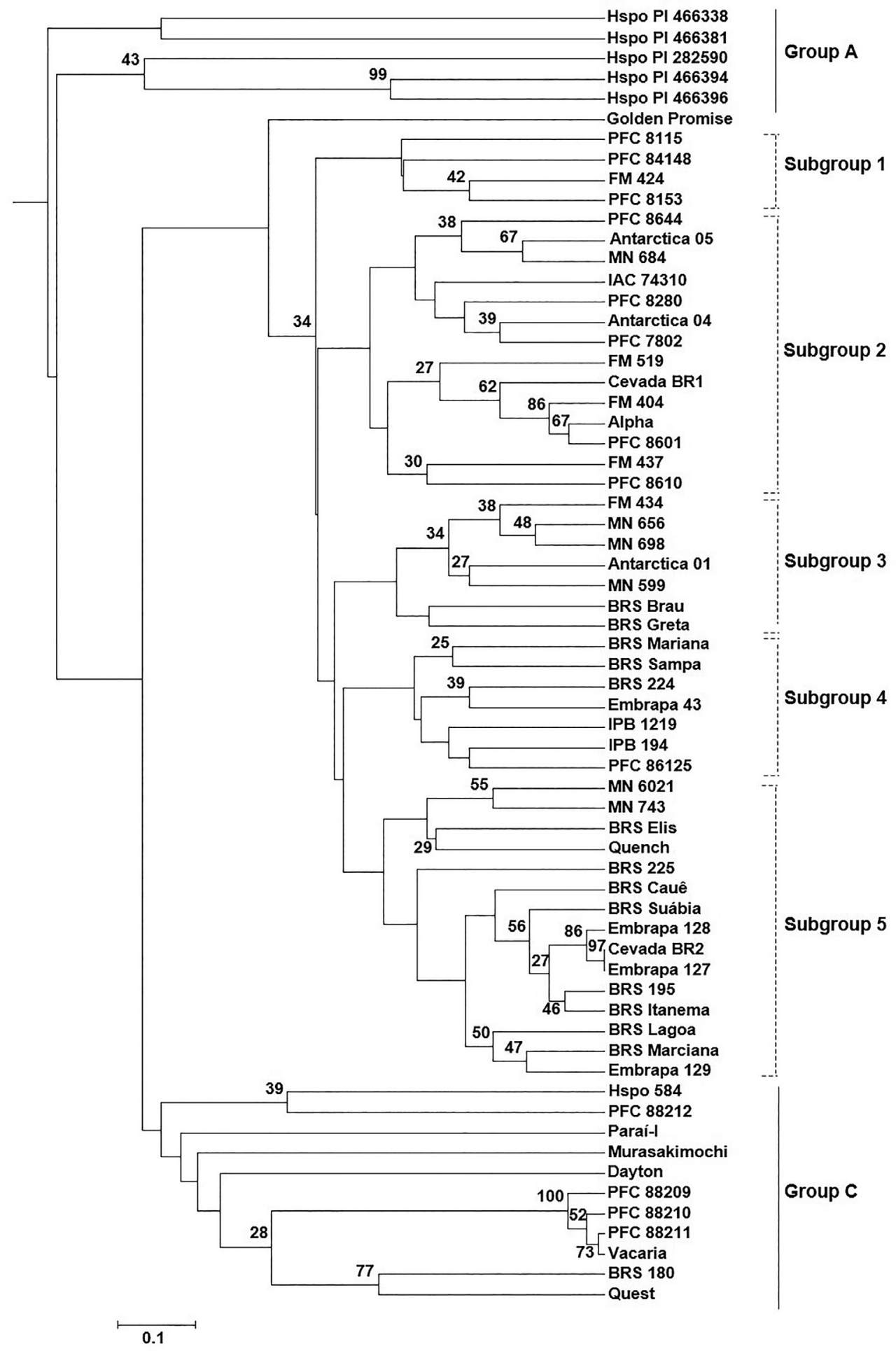

Figure 3 - UPGMA tree of barley accessions constructed based on the matrix of shared microsatellite alleles. Bootstrap values are indicated at nodes. Only bootstrap values $\geq 25 \%$ are shown.

group five, only three were developed before the year 2000. This means that cultivars released in the last years are more similar, indicating a decrease in the genetic diversity. Other indicators of the tendency to decreased genetic diversity are the lower number of alleles, the lower frequency of alleles per marker, and lower PIC values obtained for Brazilian genotypes developed after the 1980s (Figure 1).

The observation that Brazilian barleys are closely related is in agreement with other studies (Selbach and Cavalli-Molina, 2000; Kroth et al., 2005). In fact, crop breeding 
programs have drastically narrowed the genetic diversity in cultivated plants, reducing tolerance to environmental stresses (Nevo, 2007). This genetic diversity reduction may have occurred because of the selection of specific alleles that confer stability in the specific environment of Southern Brazil. An evidence of the use of common materials for obtaining the cultivars can be visualized by the analysis of Group B in the dendrogram (Figure 3). The genotypes Volla and Wpgm 626-46-25 are present in the genealogy of three accessions in subgroup one (Table 1). Alpha is an ancestor of Antarctica 04, FM 519, Cevada BR1, FM 404, and FM 437, which clustered in subgroup two (Table 1). In subgroup four, most of the accessions were developed by CNPT-Embrapa. The genotypes BRS Mariana and BRS Sampa, which were closely related, share PFC 9205 in their genealogy. The genotype IPB 194 was used in the cross that generated Embrapa 43, which was then used to obtain BRS 224 (Table 1). Most of the genotypes grouping in subgroup five have BRS 195 and Cevada BR2 in their genealogy (Table 1). Hence, barley breeding programs in Brazil should definitely consider the use of a more diverse set of materials in their crossings.

The UPGMA results (Figure 3) were in agreement with PCoA and STRUCTURE analysis (Figure 2). The three groups detected in the UPGMA plot showed a pattern correlated to the number of rows of grains on the ear and to barley type (wild or domesticated). For instance, Group A was exclusively formed by wild accessions (two-row genotypes), while all genotypes in Group C, except for the wild accession Hspo 584, were representatives of six-row barley. These results could suggest that Hspo 584 has a different geographical origin than the other wild accessions. Although it has been shown that SSR and SNP markers can clearly separate the two- and six-rowed barley groups (Hayes and Szucs, 2006; Khodayari et al., 2012), exceptions have been reported where a few two- and six-rowed genotypes showed similarity (Marmiroli et al., 1999; Brantestam et al., 2007; Lamara et al., 2013), as we also found here.

Wild barley (H. vulgare ssp. spontaneum), the progenitor of cultivated barley, is a selfing annual grass distributed over a wide ecological range that differs in water availability, temperature, soil type, altitude and vegetation, thus generating a high potential for adaptive genetic diversity against abiotic and biotic stresses. It has been reported that wild barley has developed unique mechanisms for surviving harsh environments, mainly through developing new genetic variations and alleles (Nevo and Chen, 2010). Here we detected a greater diversity in wild barley accessions when compared to domesticated ones. Higher numbers of SSR alleles and greater diversity levels of individual loci were also found for wild genotypes in comparison to cultivated barley (Saghai Maroof et al., 1994; Nandha and Singh, 2014). Another evidence for greater genetic diversity in wild barley is the higher number of private alleles de- tected (Table S2), a result that has also been reported by Nandha and Singh (2014). Interestingly, cultivars Vacaria, Paraí, and BRS 180 and breeding lines PFC 88209, PFC 88210, and PFC 88211 developed by CNPT-Embrapa, as well as three foreign cultivars (Dayton, Quest, and Murasakimochi) grouped together with one wild accession (Hspo 584) in all analyses performed here. The genetic diversity shared by these accessions and wild barley indicates the potential of these accessions as a source of alleles for breeding purposes. A close similarity between domesticated barley and one wild accession has also been reported by Nandha and Singh (2014).

In this study, the geographic origin was not clearly associated with the groups, despite previous observation that SSR markers can differentiate barleys according to their region of origin (Malysheva-Otto et al., 2006). However, other associations can be done based on genotype similarity. For instance, Group C consisted of six accessions that are feed varieties (Paraí-I, PFC 88209, PFC 88210, PFC 88211, PFC 88212, and Vacaria), whereas all accessions within Group B are malting barleys.

The highest average PIC was found for chromosome three, the same one where the highest diversity parameters were detected by Malysheva-Otto et al. (2006). Chromosome four was the one with the highest number of markers evaluated, however it showed the lowest PIC values. Among these loci, one was monomorphic and the others had PIC values below 0.50. Interestingly, chromosome four contains the $H v A A C T 1$ gene responsible for the aluminum tolerance in barley (Furukawa et al., 2007; Wang et al., 2007). Aluminum is an important constraint in Southern Brazil (Echart and Cavalli-Molina, 2001), where most of Brazilian barley is produced. It has been proposed that the low variability for aluminum tolerance in Brazilian barley indicates that significant increments through conventional breeding are unlikely (Minella, 2001). It is possible that the low variability found in chromosome four could explain the low level of aluminum tolerance diversity in Brazilian barley. Strategies must be considered to surpass the low variability for some traits in barley, allowing the increase in stress tolerance and, ultimately, yield.

In conclusion, we have detected a lower PIC value among barley genotypes bred in Brazil compared with foreign and wild genotypes. A tendency to a decrease in genetic diversity of Brazilian barley is occurring with modern materials released over the last two decades, showing lower number of alleles, lower frequency of alleles per marker, and lower PIC values in comparison to cultivars released in the 1980s. This could be partially explained by the use of common ancestors carrying important traits. The use of more diverse material could be of interest to exploit novel alleles in crop breeding programs without losing quality. Some of the genotypes used here, such as the ones present in Group C of the dendrogram, should be considered. Pri- 
vate alleles unique to Brazilian genotypes are important for future use in cultivar identification.

\section{Acknowledgments}

This work was financially supported by Agrária and Ambev (Companhia de Bebidas das Américas). CAD and JRF received fellowships from the Brazilian National Council for Scientific and Technological Development (CNPq).

\section{References}

Anderson JA, Churchill GA, Autrique JE, Tanksley SD and Sorrells ME (1993) Optimizing parental selection for genetic linkage maps. Genome 36:181-186.

Baik BK and Ullrich, SE (2008) Barley for food: characteristics, improvement, and renewed interest. J Cereal Sci 48:233242.

Bian M, Waters I, Broughton S, Zhang XQ, Zhou M, Lance R, Sun D and Li C (2013) Development of gene-specific markers for acid soil/aluminium tolerance in barley Hordeum vulgare L. Mol Breed 32:55-164.

Botstein D, White RL, Skolnick M and Davis RW (1980) Construction of a genetic linkage map in man using restriction fragment length polymorphisms. Am J Hum Genet 32:314-331.

Brantestam AK, von Bothmer R, Dayteg C, Rashal I, Tuvesson S and Weibull J (2007) Genetic diversity changes and relationships in spring barley (Hordeum vulgare L.) germplasm of Nordic and Baltic areas as shown by SSR markers. Genet Resour Crop Evol 54:749-758.

de Mori C and Minella E (2012) Aspectos econômicos e conjunturais da cultura da cevada. Passo Fundo: Embrapa Trigo, Documentos online 139, $28 \mathrm{p}$.

Doyle JJ and Doyle JL (1987) A rapid DNA isolation procedure for small quantities of fresh leaf material. Phytochem Bull 19:11-15.

Earl EA and von Holdt BM (2012) Structure Harvester: a website and program for visualizing Structure output and implementing the Evanno method. Conserv Genet Resour 4:359361.

Echart CL and Cavalli-Molina S (2001) Fitotoxicidade do alumínio: efeitos, mecanismo de tolerância e seu controle genético. Cienc Rural 31:531-541.

Echart-Almeida C and Cavalli-Molina S (2000) Hordein variation in Brazilian barley varieties Hordeum vulgare L. and wild barley H. euclaston Steud. and H. stenostachys Godr. Genet Mol Biol 23:425-433.

Evanno G, Regnaut S and Goudet J (2005) Detecting the number of clusters of individuals using the software STRUCTURE: a simulation study. Mol Ecol 14:2611-2620.

Excoffier L and Lischer HEL (2010) Arlequin suite ver. 3.5: A new series of programs to perform population genetics analyses under Linux and Windows. Mol Ecol Resour 10:564567.

Excoffier L, Smouse PE and Quattro J (1992) Analysis of molecular variance inferred from metric distances among DNA haplotypes: Application to human mitochondrial DNA restriction data. Genetics 131:479-491.
Furukawa J, Yamaji N, Wang H, Mitani N, Murata Y, Sato K, Katsuhara M, Takeda K and Ma JF (2007) An aluminumactivated citrate transporter in barley. Plant Cell Physiol. 48:1081-1091.

Falush D, Tephens MS and Pritchard JK (2003) Inference of population structure using multilocus genotype data: Linked loci and correlated allele frequencies. Genetics 164:15671587.

Feuillet C, Langridge P and Waugh R (2007) Cereal breeding takes a walk on the wild side. Trends Genet 24:25-32.

Goyal A and Ahmed M (2012) Barley: production, improvement, and uses. Crop Sci 52:2852-2854.

Gupta PK, Balyan HS, Sharma PC and Ramesh B (1996) Microsatellites in plants: a new class of molecular markers. Curr Sci 45:45-54

Hayes P and Szucs P (2006) Disequilibrium and association in barley: thinking outside the glass. Proc Natl Acad Sci USA 103:18385-18386.

Jakobsson M and Rosenberg NA (2007) CLUMPP: a cluster matching and permutation program for dealing with label switching and multimodality in analysis of population structure. Bioinformatics 23:1801-1806.

Karakousis A, Barr AR, Chalmers KJ, Ablett GA, Holton TA, Henry RJ, Lim P and Langridge P (2003) Potential of SSR markers for plant breeding and variety identification in Australian barley germplasm. Crop Pasture Sci 54:1197-1210.

Keilwagen J, Kilian B, Ozkan H, Babben S, Perovic D, Mayer KF, Poskar CH, Ordon F, Eversole K, et al. (2014) Separating the wheat from the chaff - a strategy to utilize plant genetic resources from ex-situ genebanks. Sci Rep 4:5231.

Khodayari H, Saeidi H, Roofigar AA, Rahiminejad MR, Pourkheirandish M and Komatsuda T (2012) Genetic diversity of cultivated barley landraces in Iran measured using microsatellites. Int J Biosci Biochem Bioinform 2:278-290.

Kroth MA, Ramella MS, Tagliari C, Francisco AD and Arisi ACM (2005) Genetic similarity of Brazilian hull-less and malting barley varieties evaluated by RAPD markers. Sci Agric 62:36-39.

Ladizinsky G (1998) How many tough-rachis mutants gave rise to domesticated barley? Genet Resour Crop Evol 45:411-414.

Lamara M, Zhang LY, Marchand S, Tinker NA and Belzile F (2013) Comparative analysis of genetic diversity in Canadian barley assessed by SSR, DarT, and pedigree data. Genome 56:351-358.

Ledovskoy Y, Abugalieva S and Turuspekov Y (2010) Comparative assessment of the genetic variation in wild and cultivated barley based on SSR markers. Asian Australas J Plant Sci Biotechnol 4:21-26.

Liu K and Muse SV (2005) PowerMarker: integrated analysis environment for genetic marker data. Bioinformatics 21:2128-2129.

Liu ZW, Biyashev RM and Maroof MS (1996) Development of simple sequence repeat DNA markers and their integration into a barley linkage map. Theor Appl Genet 93:869-876.

Malysheva-Otto LV, Ganal MW and Röder MS (2006) Analysis of molecular diversity, population structure and linkage disequilibrium in a worldwide survey of cultivated barley germplasm Hordeum vulgare L.. BMC Genet 7:e6

Marmiroli N, Maestri E, Liviero L, Massari A, Malcevschi A and Monciardini P (1999) Application of genomics in assessing 
biodiversity in wild and cultivated barley. Mol Ecol 8:S95S106.

Minella E (2001) Desafios e potencialidades do melhoramento genético de cevada no Brasil. In: Reunião Anual de Pesquisa de Cevada, Guarapuava. Passo Fundo: Embrapa Trigo 1:31-40.

Minella E (2005) Melhoramento de cevada. In: Borém A (ed) Melhoramento de Espécies Cultivadas, 2nd edition, Editora UFV, Viçosa, pp 275-299.

Nandha PS and Singh J (2014) Comparative assessment of genetic diversity between wild and cultivated barley using gSSR and EST-SSR markers. Plant Breed 133:28-35.

Nevo E (2007) Evolution of wild wheat and barley and crop improvement: studies at the Institute of Evolution. Isr J Plant Sci 55:251-262.

Nevo E and Chen G (2010) Drought and salt tolerances in wild relatives for wheat and barley improvement. Plant Cell Environ 33:670-685.

Nevo E, Fu YB, Pavlicek T, Khalifa S, Tavasi M and Beiles A (2012) Evolution of wild cereals during 28 years of global warming in Israel. Proc Natl Acad Sci USA 109:3412-3415.

Oliveira EJ, Pádua JG, Zucchi MI, Vencovsky R and Vieira MLC (2006) Origin, evolution and genome distribution of microsatellites. Genet Mol Biol 29:294-307.

Peakall R and Smouse PE (2006) GENALEX 6: genetic analysis in Excel. Population genetic software for teaching and research. Mol Ecol Notes 6:288-295.

Peakall R and Smouse PE (2012) GenAlEx 6.5: genetic analysis in Excel. Population genetic software for teaching and research - an update. Bioinformatics 28:2537-2539.

Pritchard JK, Stephens M and Donnelly P (2000) Inference of population structure using multilocus genotype data. Genetics 155:945-959.

Ramsay L, Macaulay M, degli Ivanissevich S, MacLean K, Cardle L, Fuller J, Edwards KJ, Tuvesson S, Morgante M, Massari A, et al. (2000) A simple sequence repeat-based linkage map of barley. Genetics 156:1997-2005.

Röder MS, Korzun V, Wendehake K, Plaschke J, Tixier MH, Leroy P and Ganal MW (1998) A microsatellite map of wheat. Genetics 149:2007-2023.

Rosenberg NA (2004) DISTRUCT: a program for the graphical display of population structure. Mol Ecol Notes 4:137-138.

Saghai Maroof M, Biyashev RM, Yang GP, Zhang Q and Allard RW (1994) Extraordinarily polymorphic microsatellite DNA in barley: species diversity, chromosomal locations, and population dynamics. Proc Natl Acad Sci USA 91:5466-5470.

Schuelke M (2000) An economic method for the fluorescent labelling of PCR fragments. Nat Biotechnol 18:233-234.

Selbach A and Cavalli-Molina S (2000) RAPD characterization of Brazilian barley Hordeum vulgare ssp. vulgare varieties. Euphytica 111:127-135.

Soto-Cerda BJ, Peñaloza EH, Montenegro AB, Rupayan AR, Gallardo MH and Salvo-Garrido H (2013) An efficient marker-assisted backcrossing strategy for enhancing barley Hordeum vulgare $\mathrm{L}$. production under acidity and aluminium toxicity. Mol Breed 31:855-866.

Varshney RK, Marcel TC, Ramsay L, Russell J, Röder MS, Stein N, Waugh R, Langridge P, Niks RE and Graner A (2007) A high density barley microsatellite consensus map with 775 SSR loci. Theor Appl Genet 114:1091-1103.

Wang J, Raman H, Zhou M, Ryan PR, Delhaize E, Hebb DM, Coombes N and Mendham N (2007) High-resolution mapping of the Alp locus and identification of a candidate gene HvMATE controlling aluminium tolerance in barley Hordeum vulgare L. Theor Appl Genet 115:265-276.

Yahiaoui S, Igartua E, Moralejo M, Ramsay L, Molina-Cano JL, Lasa JM, Gracia MP and Casas AM (2008) Patterns of genetic and eco-geographical diversity in Spanish barleys. Theor Appl Genet 116:271-282.

\section{Internet Resources}

Goudet J (2002) FSTAT, a program to estimate and test gene diversities and fixation indices. http://www.unil.ch/izea/softwares/fstat.html (accessed March 20, 2015).

\section{Supplementary Material}

The following online material is available for this article:

Table S1 - Characteristics of the SSR markers.

Table S2 - Private alleles.

This material is available as part of the online article from http://www.scielo.br/gmb

Associate Editor: Everaldo Gonçalves de Barros

License information: This is an open-access article distributed under the terms of the Creative Commons Attribution License (type CC-BY), which permits unrestricted use, distribution and reproduction in any medium, provided the original article is properly cited. 